\title{
Aerosol optical depth and fine-mode fraction retrieval over East Asia using multi-angular total and polarized remote sensing
}

\author{
T. Cheng, X. Gu, D. Xie, Z. Li, T. Yu, and H. Chen
}

State Key Laboratory of Remote Sensing Science, Jointly Sponsored by the Institute of Remote Sensing Applications of Chinese Academy of Sciences and Beijing Normal University, Beijing, China

Correspondence to: T. Cheng (cthy@irsa.ac.cn)

Received: 2 July 2011 - Published in Atmos. Meas. Tech. Discuss.: 8 September 2011

Revised: 24 January 2012 - Accepted: 1 February 2012 - Published: 6 March 2012

\begin{abstract}
A new aerosol retrieval algorithm using multiangular total and polarized measurements is presented. The algorithm retrieves aerosol optical depth (AOD), fine-mode fraction (FMF) for studying the impact of aerosol on climate change. The retrieval algorithm is based on a lookup table (LUT) method, which assumes that one fine and one coarse lognormal aerosol modes can be combined with proper weightings to represent the ambient aerosol properties. To reduce the ambiguity in retrieval algorithm, the key characteristics of aerosol model over East Asia are constrained using the cluster analysis technique based on the AERONET sun-photometer observation over East Asia, and the fine and coarse modes are not fixed but can vary. A mixing model of bare soil and green vegetation spectra and the Nadal and Breon model for the bidirectional polarized reflectance factor (BPDF) were used to simulate total and polarized surface reflectance of East Asia. By applying the present algorithm to POLDER measurements, three different aerosol cases of clear, polluted and dust are analyzed to test the algorithm. The comparison of retrieved aerosol optical depth (AOD) and fine-mode fraction (FMF) with those of AERONET sunphotometer observations show reliable results. Preliminary validation is encouraging. Using the new aerosol retrieval algorithm for multi-angular total and polarized measurements, the spatial and temporal variability of anthropogenic aerosol optical properties over East Asia, which were observed during a heavy polluted event, were analyzed. Exceptionally high values of aerosol optical depth contributed by fine mode of up to 0.5 (at $0.865 \mu \mathrm{m}$ ), and high values of fine-mode fraction of up to 0.9 , were observed in this case study.
\end{abstract}

\section{Introduction}

The impact of aerosol on climate change is considered as one of the main uncertainties in climate modeling, which has led to large efforts for improving their global monitoring (Anderson et al., 2003; Andreae et al., 2005; Charlson et al., 1969; IPCC, 2007). Climate change research requires knowledge of anthropogenic component of aerosol, which can be considered as an external cause of climate change (Charlson et al., 1992; Hansen et al., 1997). To obtain an estimate of aerosol direct radiative forcing (DRF), a measure of the anthropogenic aerosol loading and knowledge of their size distributions and refractive indices are needed (Hansen et al., 1998; Haywood and Boucher, 2005; Bellouin et al., 2005).

Even though the significance of aerosol in climate change is well recognized and several efforts have been made to model their characteristics, there exist large uncertainties (Kaufman et al., 2002; Costa et al., 2004; Bellouin et al., 2008). One of the greatest challenges in studying aerosol impacts on climate is the immense diversity, not only aerosol size, composition, and origin, but also in spatial and temporal distribution (Bates et al., 2001; Dubovik et al., 2002a, 2008). One consequence of this heterogeneity is that the impact of aerosol on climate change must be understood and quantified on a regional rather than just a global-average basis (Delene and Ogren, 2002; Mishchenko and Geogdzhayev, 2007).

Yet most assessments of aerosol DRF are based only on climate models since satellite instruments do not directly measure the anthropogenic aerosol properties. Although models are compared and validated against observations, their estimates of aerosol DRF remain uncertain (Chin et al., 
2002; Hansen et al., 2011). Kaufman et al. (2005) estimated aerosol anthropogenic component over ocean from MODIS measurements, which use the aerosol optical depth and the fine-mode fraction of aerosol over ocean to derive the anthropogenic optical depth.

The fine-mode fraction of aerosol retrieved by satellite is unfortunately not considered reliable over land surfaces (Anderson et al., 2005, 2006), where the main aerosol sources are located, because of the difficulty in discriminating the aerosol contribution from the ground in top of the atmosphere measurements (Diner et al., 2005; Hauser et al., 2005; Kokhanovsky et al., 2007, 2010; Mishchenko and Geogdzhayev, 2007). The multi-angle polarized measurements provide an alternative and robust approach for the study of aerosols over land (Deuzé et al., 2001; Chowdhary et al., 2005; Hasekamp and Landgraf, 2005, 2007; Cheng et al., 2011). Indeed, the polarized surface contribution is smaller than, or equal to, the atmospheric contribution (Waquet et al., 2009b; Litvinov et al., 2010). Moreover, polarization measurements are highly sensitive to aerosol properties as shown in different experimental and theoretical studies (Mishchenko and Travis, 1997; Cheng et al., 2010). Retrievals of aerosol properties from multi-angular, multispectral, and polarized measurements can take advantage of the different angular and polarized reflectance signatures of the surface and aerosol properties (Deuzé et al., 2001; Waquet et al., 2007, 2009a; Litvinov et al., 2011). Deuzé et al. (2001) developed POLDER retrieval algorithm only using polarized reflectance at two visible spectral channels oriented on rapid operational processing. Dubovik et al. (2011) developed a retrieval algorithm as an attempt to enhance aerosol retrieval by emphasizing statistical optimization in inversion of data from satellite sensors with spectral multi-angle polarimetric observations using statistically optimized inversion algorithm, which are time-consuming and challenging for implementation until now. Hasekamp et al. (2011) simultaneously retrieved aerosol properties and ocean parameters based on the PARASOL measurements over the ocean.

East Asia is a unique area in terms of photochemistry and aerosol loading. More research is clearly needed to better understand and accurately quantify East Asian regional climate effects. One of the more critical problems is the lack of data characterizing the optical and physical properties of tropospheric aerosols and their temporal and spatial distributions. The research presented in this paper aims to prospect the possibility of simultaneously retrieving the spectral AOD and fine-mode fraction (FMF) using polarized remote sensing and to characterize the optical and physical properties of tropospheric aerosols and their temporal and spatial distributions over East Asia. In Sect. 2 the retrieval algorithm for spectral AOD and fine-mode fraction (FMF) using multiangular, multi-spectral, total and polarized remote sensing measurements is introduced. The description of the aerosol optical properties and surface reflectance over East Asia are also presented in Sect. 2. In Sect. 3, three different aerosol cases of clear, polluted and dust are analyzed to test the algorithm. Analysis and validation of the results are presented in Sect. 4. In Sect. 5, the spatial and temporal variability of a heavy polluted event over East Asia were analyzed using the algorithm. The conclusions of the paper are summarized in Sect. 6.

\section{Aerosol retrieval algorithm}

\subsection{The East Asian regional aerosol retrieval algorithm}

Over land surface, the PARASOL aerosol operational retrieval is based on polarized measurements at 0.670 and $0.865 \mu \mathrm{m}$ (Deuze et al., 2001). Contrary to the total radiances, polarized reflectance of surfaces is small and fairly spectrally independent (Nadal and Breon, 1999; Maignan et al., 2009), and the atmospheric contribution is larger than the surface polarized reflectance. As discussed by Deuze et al. (2001), utilization of only polarized observations allows one to derive aerosol properties and to avoid the challenging issue of separation of surface and aerosol contributions into the total reflectance. The aerosol operational algorithm over land is based on a best fit between polarized measurements at 0.670 and $0.865 \mu \mathrm{m}$ and look-up tables of simulated satellite signals pre-computed for aerosol within the accumulation mode and underlying surface contributions, which can make rapid operational processing of satellite images.

The aerosol models used in the land operational algorithm are considering aerosols within only the accumulation mode (fine mode), and the contribution of the coarse mode is neglected. Although larger aerosol particles, such as desert dust, almost do not polarized sunlight and are therefore hardly detected from polarization measurements, the coarse mode can contribute to the polarization and may lead to misinterpretation of the retrieved AOD. The refractive index is taken equal to $1.47-0.01 i$, which corresponds to a mean value for aerosols resulting from biomass burning or pollution events (Dubovik et al., 2002a). The surface contribution depends on the surface type, bare soils or vegetated areas, and is estimated from a relationship using empirical coefficients adjusted for the different classes of land surfaces according to the main IGBP (International GeosphereBiosphere Programme) biotypes and the NDVI.

The PARASOL operational algorithm has successfully provided valuable aerosol retrievals from POLDER observations; however, the operational retrieval algorithm over land only considered aerosols within the accumulation mode (fine mode) and the contribution of the coarse mode is neglected. This may lead to misinterpretation of the retrieved AOD, returning only fine mode AOD, not total AOD, and definitely not fine mode fraction. To avoid this problem, the proposed retrieval algorithm uses the best combination LUT with fine and coarse mode aerosol model based on AERONET sunphotometer observation over the East Asian region. This 
Table 1. Dimensions of LUTs for aerosol retrieval.

\begin{tabular}{lrl}
\hline Variable name & No. of entries & Entries \\
\hline Wavelength & 3 & $0.490 \mu \mathrm{m}, 0.675 \mu \mathrm{m}, 0.870 \mu \mathrm{m}$ \\
Solar zenith angle (degree) & 21 & $0,4,8, \ldots, 80$ \\
View zenith angle (degree) & 21 & $0,4,8, \ldots, 80$ \\
Relative azimuth angle (degree) & 37 & $0,5,10, \ldots, 180$ \\
AOD & 10 & $0,0.1,0.2,0.3,0.5,0.8,1.0,1.2,1.5,2.0$ \\
FMF & 11 & $0,0.1,0.2, \ldots, 1$ \\
\hline
\end{tabular}

study is focusing on an improvement of the aerosol model to reflect local characteristics and its integration within the retrieval procedure. The two main aerosol parameters (AOD and FMF) were simultaneously retrieved using POLDER measurements (Deschamps et al., 1994) to study the aerosol effect on climate change.

The algorithm uses the total and polarized radiances at 0.670 and $0.865 \mu \mathrm{m}$ and assumes that the size distribution follows a combination of two lognormal aerosol size distributions, one in the fine or accumulation mode and one in the coarse mode. The important advantage of the multi-angular, multi-spectral, total and polarized radiation measurements enables us to retrieved aerosol optical depth with size information simultaneously.

The atmosphere-surface system is assumed as plane parallel, so the optical properties of atmosphere and surface depend only on the vertical coordinate (Hansen and Travis, 1974). A vector radiative transfer model is used with the corresponding geometry $\left(\theta_{s}, \theta_{v}, \varphi\right)$ for the given aerosol optical depth and other aerosol optical properties (single scattering albedo, asymmetry parameter). In this study, the RT3 vector radiative transfer mode (Evans and Stephens, 1991) is used, which simulates radiation fields in the atmosphere-land system assuming plane parallel atmosphere.

A lookup tables (LUT) approach is adopted to retrieve AOD and FMF. The LUTs are constructed based on extensive analysis of aerosol optical properties obtained from AERONET sun-photometer observations (Holben et al., 1998).

The algorithm of this paper assumes that one fine and one coarse lognormal aerosol mode can be combined with proper weightings to represent the ambient aerosol properties (Remer et al., 2005). There are six fine modes and six coarse modes in the algorithm. In order to improve the accuracy of aerosol retrieval using remote sensing, the fine and coarse aerosol mode size distribution are determined based on extensive analysis of aerosol optical properties obtained from AERONET sun-photometer observations (Dubovik and King, 2000) over East Asia.
The inversion is based on determining which of the 36 combinations of fine and coarse aerosol models and their relative optical contributions best mimics the TOA spectral polarized measurements. The total and polarized reflectance from each mode is combined as follows (Wang and Gordon, 1994):

$$
\begin{gathered}
R^{\mathrm{LUT}}\left(\tau, \theta_{\mathrm{s}}, \theta_{\mathrm{v}}, \varphi_{r}\right)=\mathrm{FMF} \cdot R^{\mathrm{fine}}\left(\tau, \theta_{\mathrm{s}}, \theta_{\mathrm{v}}, \varphi_{r}\right) \\
+(1-\mathrm{FMF}) \cdot R^{\text {coarse }}\left(\tau, \theta_{\mathrm{s}}, \theta_{\mathrm{v}}, \varphi_{r}\right)
\end{gathered}
$$

where $R^{\mathrm{LUT}}\left(\tau, \theta_{\mathrm{s}}, \theta_{\mathrm{v}}, \varphi_{\mathrm{r}}\right)$ is the weighted average total and polarized reflectance of an atmosphere with a pure fine mode and optical depth and the total and polarized reflectance of an atmosphere with a pure coarse mode with the same optical depth.

The dimensions of calculated LUT are summarized in Table 1.

Figure 1 represents the flowchart of POLDER algorithm to simultaneously retrieve aerosol optical properties. In the algorithm, cloud pixels are detected and masked out first since the accuracy of aerosol properties retrievals is subject to cloud masking due to its strong signal. To determine clear sky pixels and heavy aerosol plumes, cloud pixels were filtered out using the POLDER clear sky discrimination method (Bréon, and Colzy, 1999), which used relaxed threshold value and the $3 \times 3$ pixel technique or inhomogeneous cloud detection.

From the LUT of total reflectance, TOA reflectance at $0.490 \mu \mathrm{m}$ and surface reflectance contribution, the initial total AOD are retrieved using the least mean squares fitting method. After that, the initial total AOD, LUT of polarized reflectance, TOA polarized reflectance at $0.675 \mu \mathrm{m}$, $0.870 \mu \mathrm{m}$, and surface polarized reflectance contribution are used to retrieve the FMF for combination of fine- and coarsemode, and the adjusted total AOD.

The retrieval algorithm employs the least mean squares fitting method in the form of a series of numerical iteration procedures to search for the computed total and polarization reflectance that best match the measured total and polarized reflectance. The residual term is defined as: 


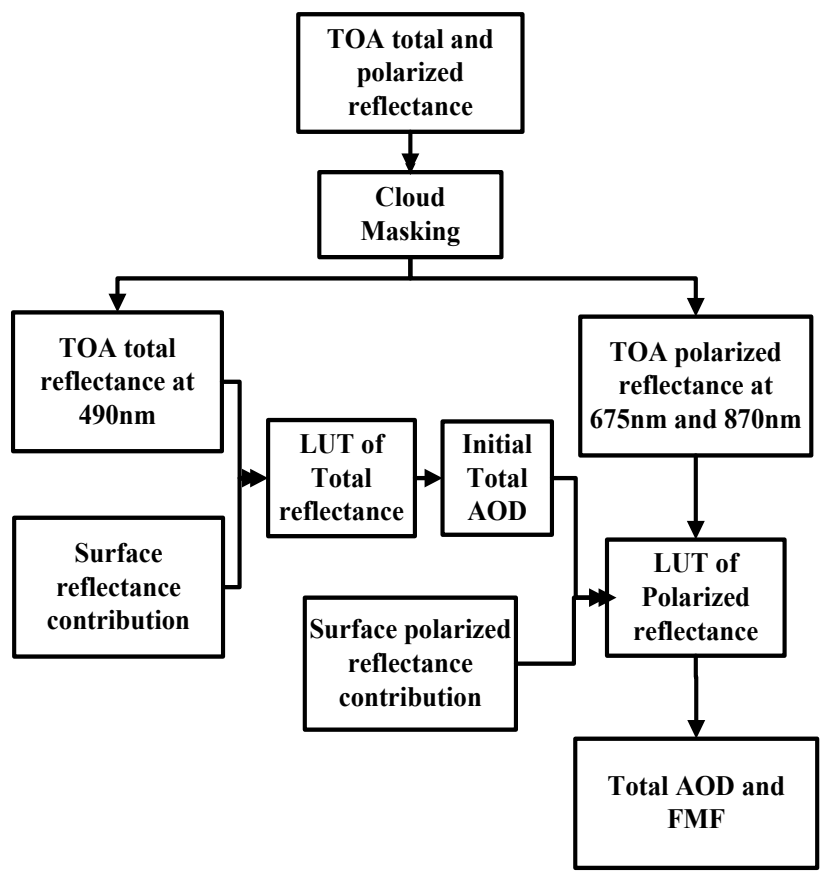

Fig. 1. Flowchart of aerosol optical properties from multi-angular, multi-spectral, total and polarized radiation measurements from POLDER.

$$
\begin{aligned}
\chi_{1} & =\sum_{n=1}^{16}\left[R_{\mathrm{comp}}^{0.490 \mu \mathrm{m}}\left(\lambda, \mathrm{AOD}, \mathrm{FMF}, \mu_{\mathrm{s}}, \mu_{\mathrm{v}}, \Delta \phi\right)\right. \\
& \left.-R_{\mathrm{mea}}^{0.490 \mu \mathrm{m}}\left(\lambda, \mathrm{AOD}, \mathrm{FMF}, \mu_{\mathrm{s}}, \mu_{\mathrm{v}}, \Delta \phi\right)\right]^{2} \\
\chi_{2} & =\sum_{w=1}^{2} \sum_{n=1}^{16}\left[R_{\mathrm{comp}}^{\mathrm{p}}\left(\lambda_{\mathrm{w}}, \mathrm{AOD}, \mathrm{FMF}, \mu_{\mathrm{s}}, \mu_{\mathrm{v}}, \Delta \phi\right)\right. \\
& \left.-R_{\text {mea }}^{\mathrm{p}}\left(\lambda_{\mathrm{w}}, \mathrm{AOD}, \mathrm{FMF}, \mu_{\mathrm{s}}, \mu_{\mathrm{v}}, \Delta \phi\right)\right]^{2}
\end{aligned}
$$

where $w$ is the number of spectral bands, and $n$ is the scattering angle observations for each pixel. $R_{\text {comp }}^{0.490 \mu \mathrm{m}}$ and $R_{\text {mea }}^{0.490 \mu \mathrm{m}}$ are computed and measured total reflectance at $0.490 \mu \mathrm{m}$; $R_{\text {comp }}^{\mathrm{p}}$ and $R_{\text {mea }}^{\mathrm{p}}$ are computed and measured polarized reflectance at $0.675 \mu \mathrm{m}$ and $0.870 \mu \mathrm{m}$, respectably. $\mu_{\mathrm{s}}$ is the cosine of solar zenith angle, $\mu_{\mathrm{v}}$ is the cosine of view zenith angle, and $\Delta \phi$ is the relative azimuth angle, respectively. A liner mixing model of vegetation and bare soil spectra (von Hoyningen et al., 2003) were used to estimated surface reflectance, while the Nadal and Breon (1999) was used to estimate the polarized reflectance.

\subsection{Sensitivity study}

In order to test the ability of the inversion algorithm, we have studied the relationship between the polarized reflectance at $0.675 \mu \mathrm{m}, 0.870 \mu \mathrm{m}$ based on the numerical simulation
Table 2. Detailed parameters of fine model and coarse model.

\begin{tabular}{lcccc}
\hline $\begin{array}{l}\text { Aerosol } \\
\text { models }\end{array}$ & $r_{\mathrm{m}}(\mu \mathrm{m})$ & $S$ & $m(0.675 \mu \mathrm{m})$ & $m(0.870 \mu \mathrm{m})$ \\
\hline Fine & 0.192 & 0.504 & $1.47-0.010 i$ & $1.47-0.010 i$ \\
Coarse & 2.580 & 0.568 & $1.53-0.003 i$ & $1.53-0.003 i$ \\
\hline
\end{tabular}

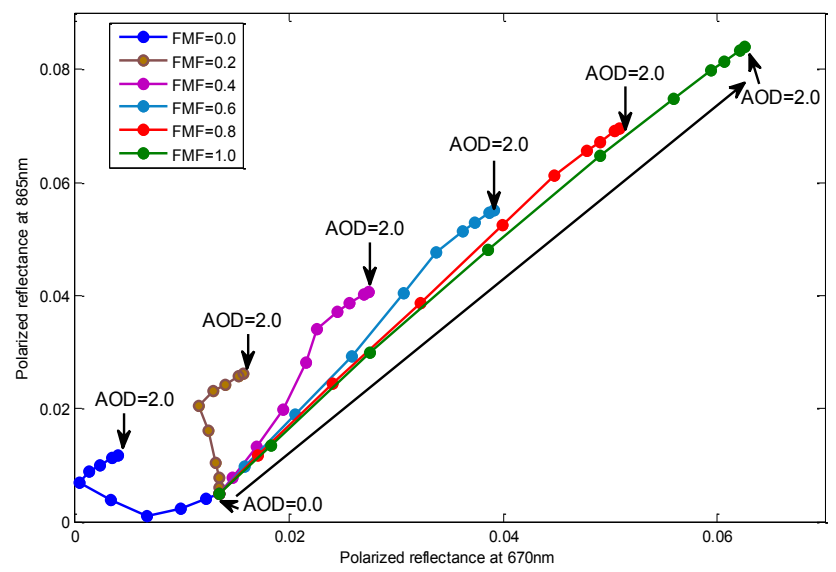

Fig. 2. Two-dimensional polarized reflectance correlation diagram in terms of the FMF $(0.0,0.2,0.4,0.6,0.8,1.0)$ and AOD $(0.0$, $0.1,0.2,0.3,0.5,0.8,1.0,1.2,1.5,2.0)$ for two wavelengths of $0.675 \mu \mathrm{m}, 0.870 . \mu \mathrm{m}$ in the calculation for a solar zenith angle is $50^{\circ}$, a satellite viewing angle is $30^{\circ}$, and the azimuth relative angle is $180^{\circ}$, the type of the surface is black surface.

(LUT) as a function of aerosol optical depth, and FMF (Fig. 2). The solar zenith angle is $50^{\circ}$, the satellite viewing angle is $30^{\circ}$, and the azimuth relative angle is $180^{\circ}$. The solid lines represent constant FMF (from 0.0 to 1.0), while the symbols on the solid lines represent different AOD (from 0.0 to 2.0). The parameters of aerosol models are listed in Table 2. The type of surface is black surface, so the contribution of surface to reflectance and polarized reflectance can be neglected.

From the 2-dimensional diagram for a given geometry, it is noted that there is a strong sensitivity of the combination of polarized reflectance at $0.675 \mu \mathrm{m}, 0.870 \mu \mathrm{m}$ to FMF when the AOD is confirmed. The sensitivity to FMF decrease with the AOD decrease, and the accuracy of retrieved FMF is very low when the AOD is smaller than 0.1 at $0.870 \mu \mathrm{m}$. There is also a strong sensitivity of the combination of polarized reflectance at $0.675 \mu \mathrm{m}, 0.870 \mu \mathrm{m}$ to AOD when the FMF is confirmed, especially for higher FMF (fine aerosol mode), and the sensitivity to AOD decrease with the AOD increase, which means it is very hard to accurately detect the AOD with AOD lager than 1.5 at $0.870 \mu \mathrm{m}$. The sensitivity to FMF is larger than that of AOD, so the FMF can be retrieved using the initial total AOD from radiance measurements, and then 
the adjusted total AOD can be retrieved using the FMF. The accuracy of the FMF can be accepted when the AOD is larger than 0.1 at $0.870 \mu \mathrm{m}$, and the AOD cannot be detected when the AOD is larger than 1.5 at $0.870 \mu \mathrm{m}$.

\subsection{Aerosol models over East Asia}

Aerosols with different properties originate from various sources: sea-salt particles, desert dust, biomass burning and industrial combustions. Aerosols are characterized by their shape, their size, their chemical composition and total amount, which in turn determine their radiative properties. In a good approximation, the optical properties of a particle are determined by the refractive index and size distribution. The refractive index depends on the chemical composition of the particles.

Wang and Gordon (1994) described a method by which the aerosol component of the radiance at TOA can be synthesized from the radiances generated by individual components of the aerosol size-refractive-index distribution. The method is exact in the single-scattering approximation and usually reproduces the aerosol contribution with an error $<2-3 \%$ (and only rarely $>3-4 \%$ ) for aerosol optical thickness as large as 0.5 at $865 \mathrm{~nm}$. Only when the aerosol is strongly absorbing can the method fail. They concluded that the method can provide a basis for the estimation of aerosol properties with Earth-orbiting sensors.

In this paper, we used the Wang and Gordon method to calculate the aerosol component of the radiance at TOA by synthesizing the radiances generated by individual components of the fine mode and coarse mode. The aerosol size distribution used in this study for the fine and coarse model is the mono-modal lognormal size distribution described as follows by Eq. (3),

$\frac{\mathrm{d} V(r)}{\mathrm{d} \ln r}=\frac{C}{S \sqrt{2 \pi}} \exp \left(-\frac{\left[\ln \left(r / r_{\mathrm{m}}\right)\right]^{2}}{2 S^{2}}\right)$,

where $C$ is the volume concentration, $r_{\mathrm{m}}$ is the volume median logarithm of the radius, and $S$ is the standard deviation of the logarithm of the radius. In order to improve the aerosol model of retrieval algorithm to reflect local characteristics, the detailed parameters of fine model and coarse model size distribution of this study are retrieved from the regional aerosol modes of East Asia based on the AERONET measurements.

Lee and Kim (2010) have studied the aerosol models using the cluster analysis technique (Omar et al., 2005) based on the AERONET sun-photometer observation over East Asia. They defined six aerosol optical modes with the bimodal lognormal size distribution. Each aerosol model has somewhat different values of refractive index at particular wavelengths, median particles radius, and standard deviation of size distribution. The six cluster aerosol models of East Asia can represent realistic possibilities of the aerosol properties. The
Table 3. Detailed parameters of fine model and coarse model.

\begin{tabular}{lcccc}
\hline $\begin{array}{l}\text { Aerosol } \\
\text { models }\end{array}$ & $r_{\mathrm{m}}(\mu \mathrm{m})$ & $S$ & $m(0.675 \mu \mathrm{m})$ & $m(0.870 \mu \mathrm{m})$ \\
\hline Fine 1 & 0.219 & 0.531 & $1.480-0.0086 i$ & $1.485-0.0088 i$ \\
Fine 2 & 0.257 & 0.535 & $1.483-0.0074 i$ & $1.483-0.0078 i$ \\
Fine 3 & 0.208 & 0.619 & $1.549-0.0024 i$ & $1.537-0.0023 i$ \\
Fine 4 & 0.192 & 0.504 & $1.458-0.0100 i$ & $1.468-0.0102 i$ \\
Fine 5 & 0.177 & 0.474 & $1.472-0.0088 i$ & $1.482-0.0090 i$ \\
Fine 6 & 0.162 & 0.538 & $1.535-0.0037 i$ & $1.536-0.0036 i$ \\
Coarse 1 & 2.724 & 0.583 & $1.480-0.0086 i$ & $1.485-0.0088 i$ \\
Coarse 2 & 2.580 & 0.568 & $1.483-0.0074 i$ & $1.483-0.0078 i$ \\
Coarse 3 & 2.915 & 0.618 & $1.458-0.0100 i$ & $1.468-0.0102 i$ \\
Coarse 4 & 2.265 & 0.656 & $1.472-0.0088 i$ & $1.482-0.0090 i$ \\
Coarse 5 & 2.286 & 0.594 & $1.535-0.0037 i$ & $1.536-0.0036 i$ \\
Coarse 6 & 2.241 & 0.531 & $1.549-0.0024 i$ & $1.537-0.0023 i$ \\
\hline
\end{tabular}

The size distribution parameters are based on a lognormal distribution. " $m$ " is the refractive index at the $0.675,0.870 \mu \mathrm{m}$ wavelengths.

detailed parameters of the fine and coarse model of this study are retrieved from the six cluster aerosol models of East Asia, which are described in Table 3.

The complex refractive index and size distributions as given by aerosol models were used to study the scattering properties of aerosol particles (single scattering albedo, asymmetry parameter and the phase matrix). The fine aerosol models are assumed to be spherical particles which can use the Mie model (Wiscombe, 1981) to calculate the scattering properties of the model. The coarse aerosol models are assumed to be spheroids particles which can use the T-matrix and geometric-optics-integral-equation to calculate the scattering properties of the model (Dubovik et al., 2002b).

\subsection{Surface reflectance}

A precise estimate of the radiation (including polarization of radiation) reflected by the surface is crucial for remote sensing of aerosol properties over land. The operational aerosol retrieval algorithm by Deuze et al. (2001) over land relies only on the PARASOL measurements of polarized reflectance and, correspondingly, it does not consider the detailed directional scattering properties of total reflectance by land surface.

The modeling of the reflectance by the land surface has been adjusted to the needs of newly developed POLDER/PARASOL retrieval. A liner mixing model of vegetation and bare soil spectra (von Hoyningen et al., 2003) was used to estimated surface reflectance using the following expression:

$\rho_{\text {surf }}(\lambda)=\omega\left[\mathrm{NDVI} \cdot \rho_{\mathrm{Veg}}(\lambda)+(1-\mathrm{NDVI}) \cdot \rho_{\mathrm{Soil}}(\lambda)\right]$

where $\lambda$ is the wavelength, $\rho_{\mathrm{Veg}}(\lambda)$ and $\rho_{\text {Soil }}(\lambda)$ are spectral reflectance of "green vegetation" and "bare soil", respectively. $\omega$ is the empirical weighting factor for the surface 
Table 4. Detailed parameters of Nadal and Breon model.

\begin{tabular}{lllr}
\hline Surface type & NDVI & $\alpha \times 100$ & $\beta$ \\
\hline \multirow{2}{*}{ Forest } & $0-0.15$ & 0.70 & 120 \\
& $0.15-0.3$ & 0.75 & 125 \\
& $\geq 0.3$ & 0.65 & 120 \\
& $0-0.15$ & 1.50 & 90 \\
\hline Shurbland & $0.15-0.3$ & 0.95 & 120 \\
& $\geq 0.3$ & 0.70 & 140 \\
& $0-0.15$ & 1.30 & 90 \\
\hline Low vegetation & $0.15-0.3$ & 0.95 & 90 \\
& $\geq 0.3$ & 0.75 & 130 \\
\hline Desert & $0-0.15$ & 2.5 & 45 \\
& $\geq 0.15$ & 2.5 & 45 \\
\hline
\end{tabular}

reflectance level at $0.66 \mu \mathrm{m}$, which can be used tune spectral surface reflectance.

This method is useful in surface reflectance determination because it accounts for the dependence of the surface reflectance on the vegetation fraction and scattering angle. Thus, the method enables the investigation of AOT over land, yielding the regional turbidity situation as well as the identification of aerosol sources like large cities, large fire plumes, haze, small scale dynamical events and also thin cirrus clouds.

Many experimental studies have shown that surfacepolarized reflectance is mainly generated by single reflection of incident radiation off surface facets. Most theoretical models developed for approximating observed BPDF are based on the Fresnel equations of light reflection from the surface. For example, Nadal and Breon have proposed simple two-parameter non-linear function of the Fresnel reflection for characterization of atmospheric aerosol over land surface based on POLDER observations of land surface. Based on these observations, the bidirectional polarized reflectance distribution functions (BPDF) of different surface have been developed for vegetation cover and bare soil.

The choice of BPDF model is of crucial importance because land surface exhibit a wide variety of architecture and radiative properties. In this study, the experimental model of Nadal and Breon (1999) - based on NDVI classification - was used to estimate the polarized reflectance in study region. From the observations collected by the POLDER instrument between November 1996 and June 1997, Nadal and Bren developed a semi-empirical model of the surface polarized reflectance:

$R_{\mathrm{p}}^{\text {surf }}\left(\theta_{\mathrm{s}}, \theta_{\mathrm{v}}, \varphi_{\mathrm{r}}\right)=\alpha\left[1-\exp \left(-\beta \frac{F_{\mathrm{p}}(\gamma)}{\mu_{\mathrm{s}}+\mu_{\mathrm{v}}}\right)\right]$

where $\alpha$ and $\beta$ are empirical coefficients that are determined by the normalized difference vegetation index of the

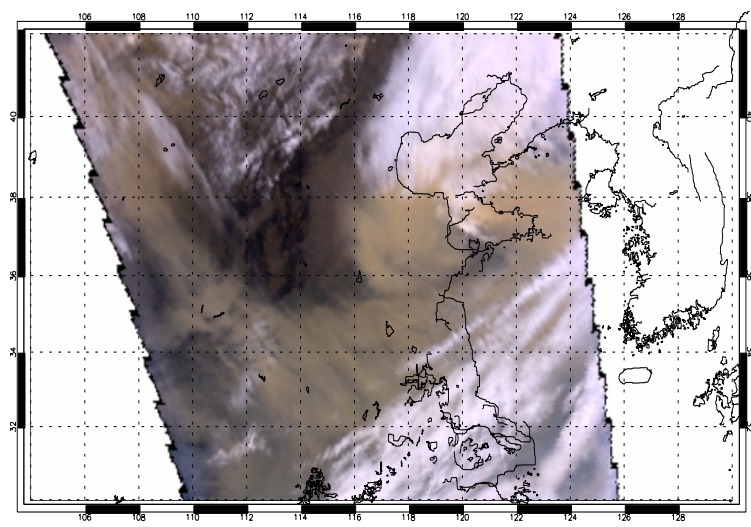

RGB image $(0.44,0.565,0.675 \mu \mathrm{m})$ capture by POLDER-20/03/2010
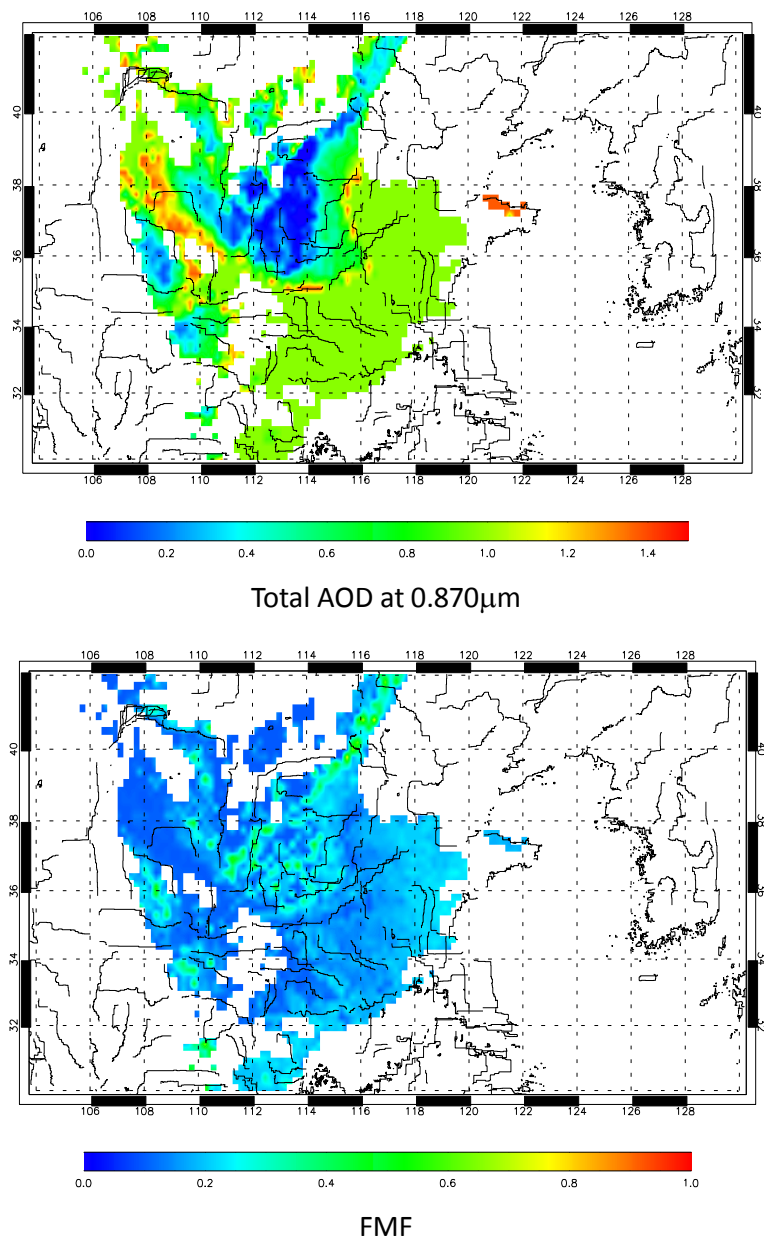

Fig. 3. Retrieved products from multi-angular, multi-spectral, total and polarized measurements on 20 March 2010.

observed surface and the ground type classification given by high space resolution airborne remote sensing data. Table 4 shows the detailed parameters of Nadal and Breon model corresponding to typical surface type.

It should be noted, however, that the von Hoyningen et al. (2003) and Nadal and Breon (1999) formulations, chosen 


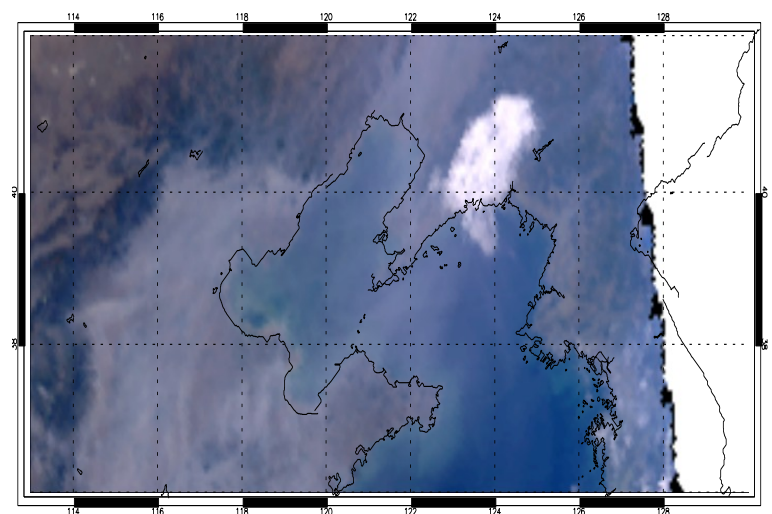

RGB image $(0.44,0.565,0.675 \mu \mathrm{m})$ capture by POLDER-06/10/2010
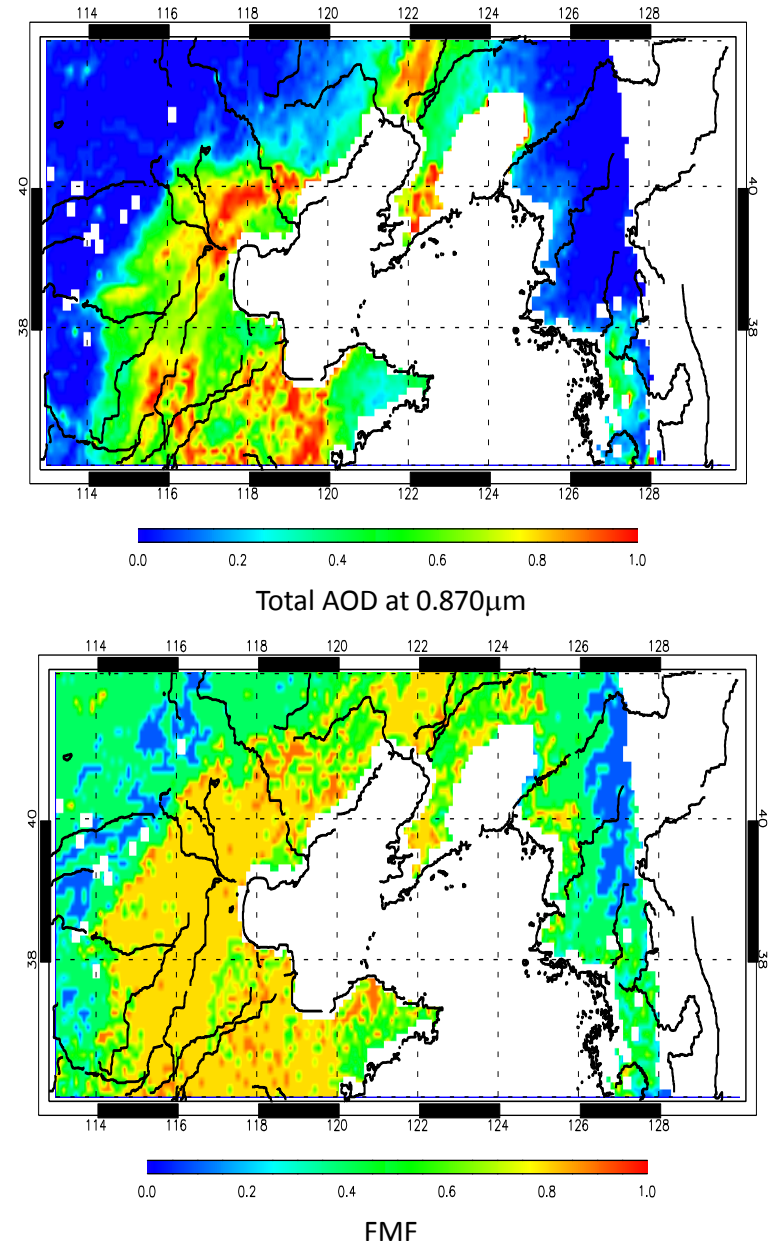

Fig. 4. Retrieved products from multi-angular, multi-spectral, total and polarized measurements on 6 October 2010.

as primary models for BRDF and BPDF in the present algorithm, have limited accuracy (e.g. see Litvinov et al., 2010, 2011). For example, the von Hoyningen et al. (2003) method with using NDVI is that NDVI calculated from top of atmosphere radiances is affected by aerosol. In heavy aerosol loading, NDVI decreases and the fraction of bare soil will

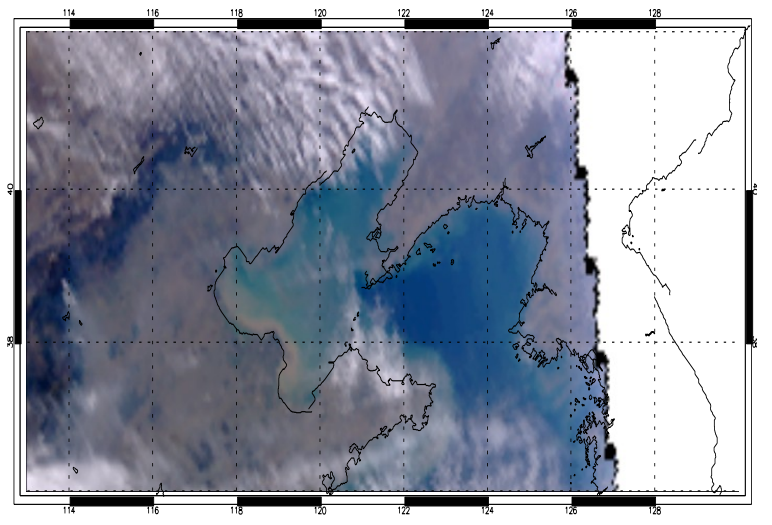

RGB image $(0.44,0.565,0.675 \mu \mathrm{m})$ capture by POLDER-25/10/2010
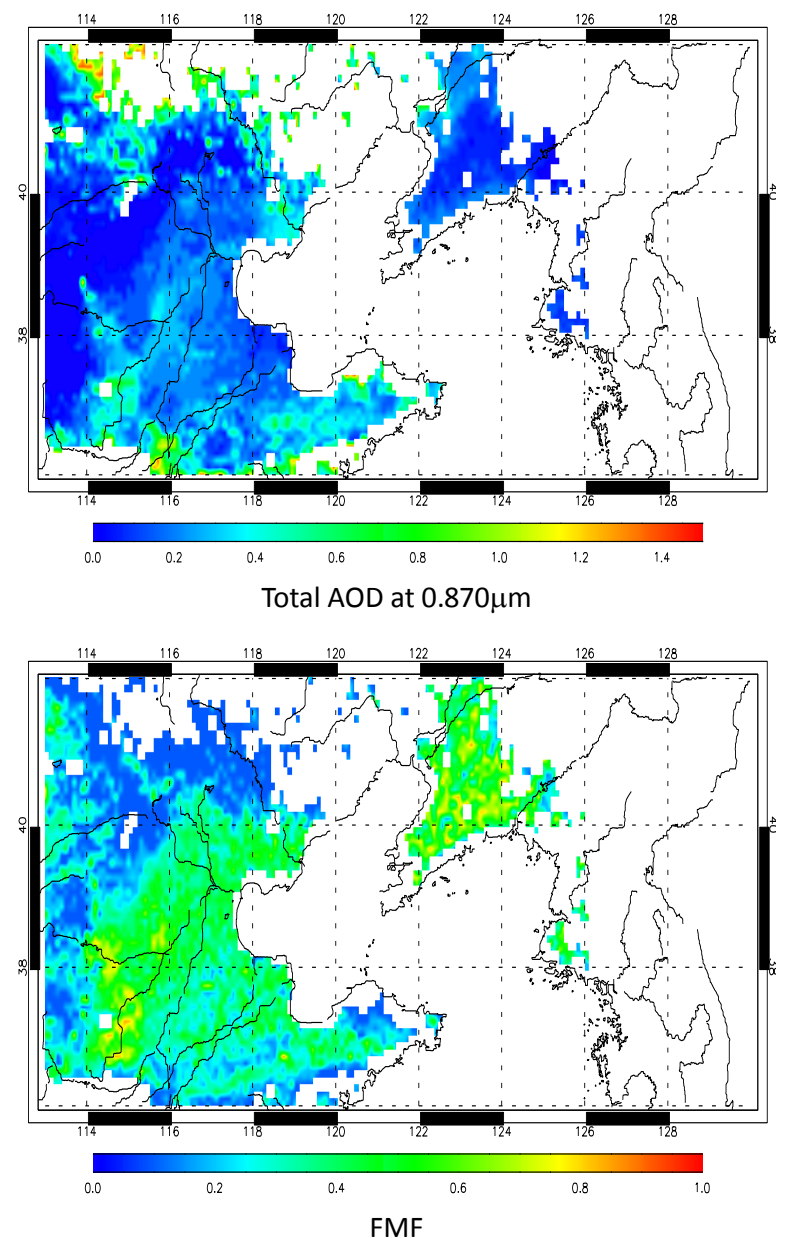

Fig. 5. Retrieved products from multi-angular, multi-spectral, total and polarized measurements on 25 October 2010.

be artificially increased. In order to improve the accuracy of the von Hoyningen et al. (2003) method, the NDVI were derived from the PARASOL measurements on the clear-sky conditions over a 30 day period. 

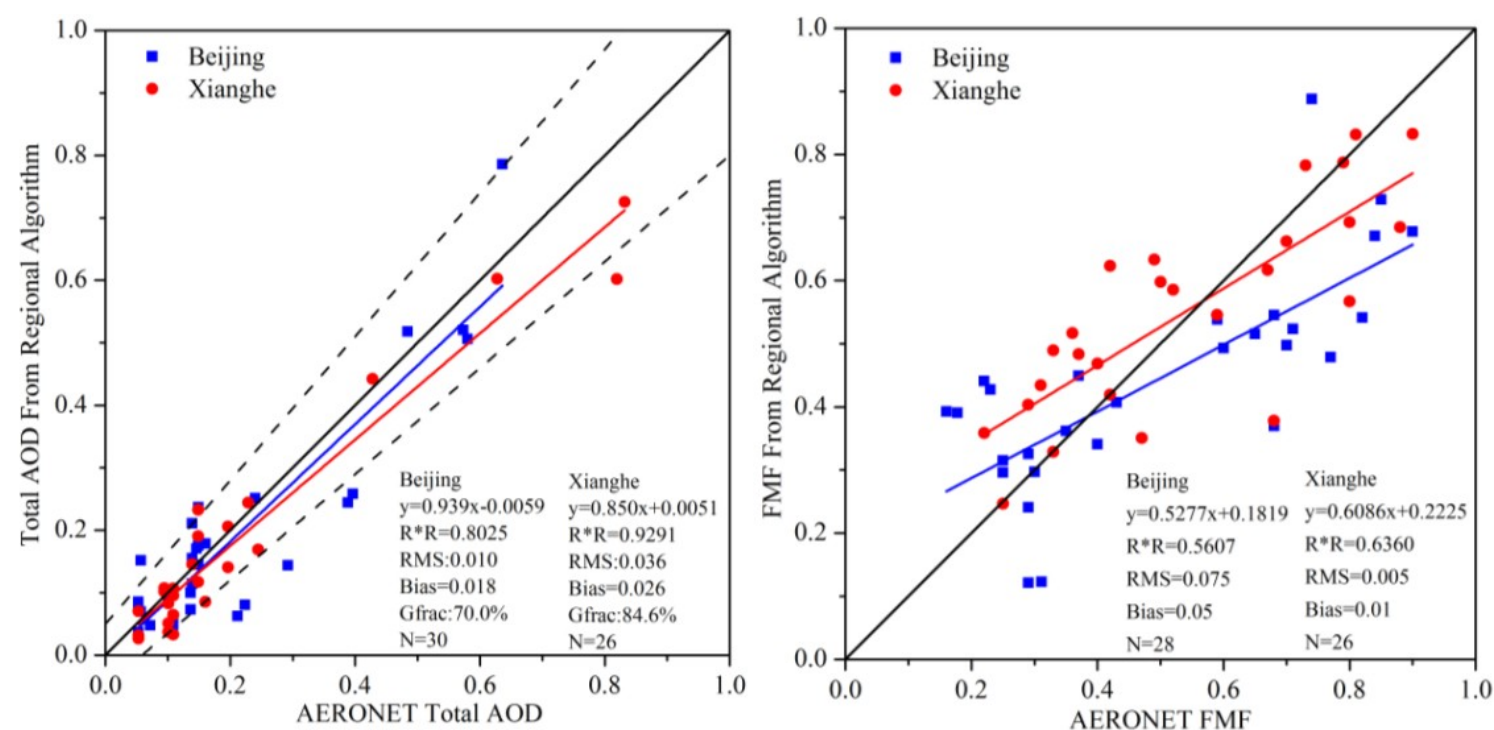

Fig. 6. Comparison of Total AOD and FMF retrieved present regional algorithm with those of AERONET observations at Beijing and Xianghe from September to December in 2010.

\section{Retrieval results}

To evaluate the performance of the developed algorithm, three different aerosol cases are selected, and retrieval of aerosol optical depth and fine-mode fraction is performed by using TOA multi-angular, multi-spectral, total and polarized measurements. Figures 3-5 show the false-color images captured by the POLDER on PARASOL satellite, AOD, and FMF from the developed algorithm on 20 March, 6 October, and 25 October in 2010, respectively.

Figure 3 shows dust case on 20 March 2010 with thick yellowish aerosol layer in the true-color image. The AOD at $0.870 \mu \mathrm{m}$ increases over 1.0, and the FMF ranges from 0.2 to 0.3 inferring mixed cases dominate with coarse-mode. Figure 4 shows the thick aerosol layer with AOD over 1.0 is observed over North China Plain with grayish and brownish color in true-color image. The FMF ranges from 0.6 to 0.9 representing the dominance of fine mode aerosol. Figure 5 shows the thin aerosol layer with AOD about 0.2 and FMF about 0.6 inferring mixed cases. From Figs. 3-5, we can see the spatial variability distribution of the three different cases in Northeast China.

\section{Analysis and validation}

It is essential to have highly accurate ground-based measurements to evaluate the aerosol optical properties derived using satellite remote sensing. To estimate the accuracy of the regional algorithm, the results (Total AOD and FMF) were compared to AERONET sun-photometer measurements (Kleidman et al., 2005) at Beijing and Xianghe, respectively.
For theses comparison, the useful ground measurement needs the following conditions to be met: approximate simultaneity between satellites overpass and sun-photometer measurements (30 $\mathrm{min}$ before and after the overpass of the sensor), cloudless conditions and good quality sun photometer data. These spatially-averaged Total AODs and FMFs from regional algorithm and temporally-averaged Total AODs and FMFs from AERONET measurements were used to validate the regional algorithm. The retrieval AODs are in good agreement with that from the ground based sun photometer measurements with a linear slope of 0.939 at Beijing and 0.850 at Xianghe, the correction coefficient of $R \times R=0.8025$ at Beijing and $R \times R=0.9291$ at Xianghe, respectively (Fig. 6). Figure 6 shows a correlation between FMFs retrieved from regional algorithm and AERONET sun-photometer measurements (liner slope $=0.5277, R \times R=0.5607$ at Beijing and liner slope $=0.6086, R \times R=0.6360$ at Xianghe). This preliminary validation is encouraging. However, the limited number of cases means that further, more comprehensive validations are needed.

In order to compare the products from regional algorithm with the products (fine mode AOD) from operational algorithm of PARASOL, the fine mode AOD of regional algorithm were retrieved from total AOD and FMF. Figure 7 shows the spatial distributions of the fine AOD from regional algorithm (left-hand side column) and operational algorithm (right-hand side column) for the three aerosol cases (clean, polluted, and dusty cases), respectively. The products from regional algorithm provide much more detail than those from operational algorithm, although the products exhibited a similar fine AOD distribution. The products from operational algorithm are lower that the products of regional algorithm, 

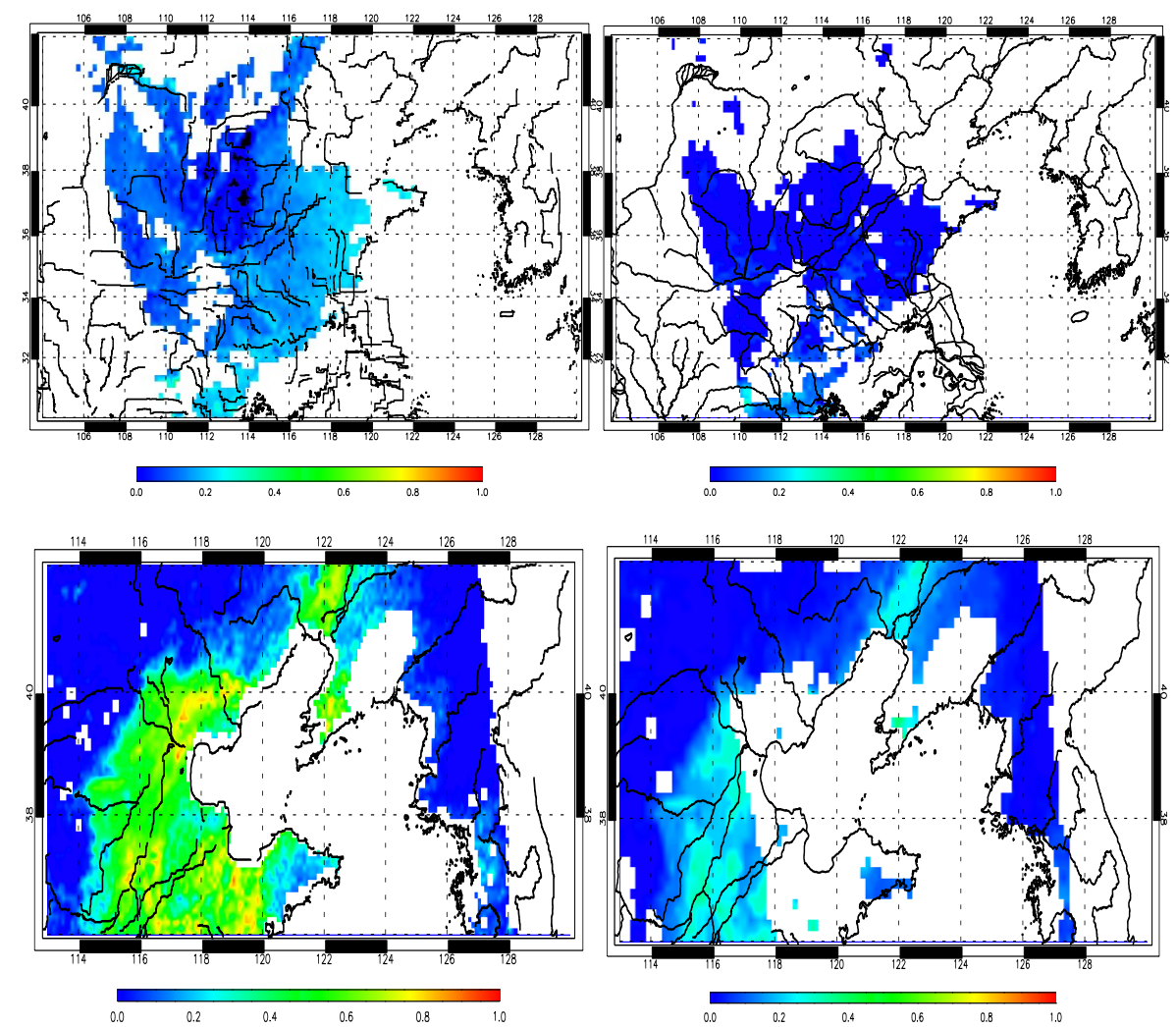

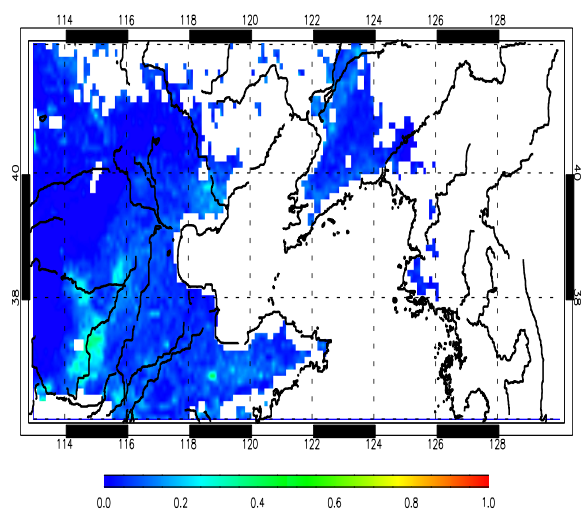

Fine AOD from regional algorithm

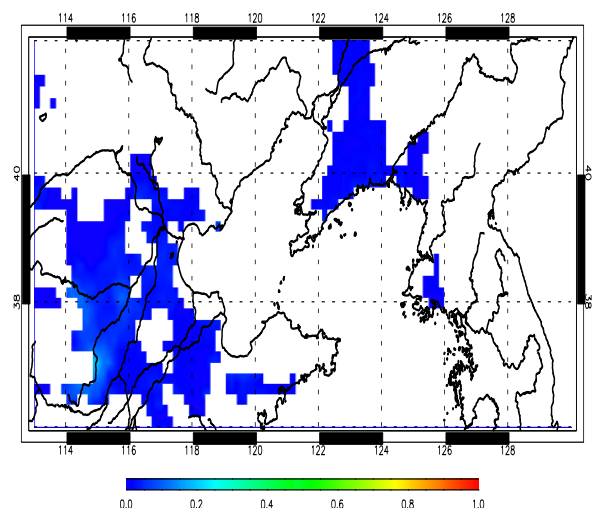

Fine AOD from operational algorithm

Fig. 7. Fine AOD from regional algorithm (left panel) and operational algorithm (right panel) for an Asian dust case (upper panel) on 20 March 2010, a polluted case (middle panel) on 6 October 2010, and a clean case (lower panel) on 25 October 2010, respectively.

probably due to the uncertainty in the aerosol model and surface reflectance.

In order to compare the products from regional algorithm and those from operational algorithm, the fine AODs were compared to fine AOD from AERONET sun-photometer measurements at Beijing and Xianghe, respectively. Figures 8 and 9 show the correlation between fine AOD from operational algorithm and regional algorithm and fine AOD from AERONET measurements at Beijing and Xianghe, respectively. The liner slope of regional algorithm is 0.948, $R \times R=0.853$ at Beijing and 1.228, $R \times R=0.973$ at Xianghe, while the liner slope of operational algorithm is $0.588, R \times R=0.928$ at Beijing and $0.555, R \times R=0.878$ at Xianghe.

\section{Application}

To evaluate the performance of the developed algorithm, a polluted aerosol event over East Asia, which is observed on 


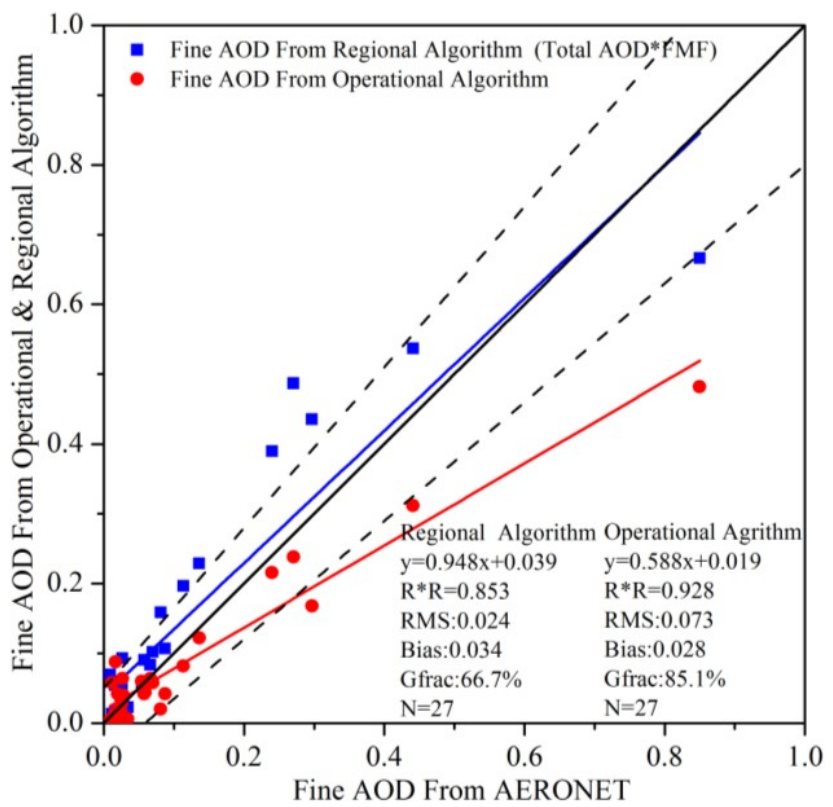

Fig. 8. Comparison of fine AOD retrieved present algorithm with those of operational algorithm at Beijing from September to December in 2010 .

15-22 November 2010, is selected. East Asia is affected by aerosols with different optical properties from fine- to coarse mode. The retrieval of AOD and FMF is performed using TOA multi-angle total and polarized reflectance from POLDER onboard PARASOL satellite.

Figure 10 shows the true-color images captured by the POLDER on PARASOL satellite over the East Asia during 15-22 November 2010. The thickest of the gray-brown aerosols conforms to the North China Plain and the mountain landscape to its south, obscuring the coastlines of Bo Hai and the Yellow Sea. The featureless gray-brown aerosols are so thick that the ground is not visible in parts of the North China Plain.

The fine-mode fraction (FMF), and aerosol optical depth contributed by fine mode (Fine AOD) retrieved using Total AOD and FMF, are shown in Figs. 11-12, respectively, except for the 19 November and 21 November due to the cloud contaminated.

From Fig. 11, we can see that the FMF increased from 0.4 on 15 November to 1.0 on 18 November, and then decreased from 0.9 on 20 November to 0.4 on 22 November. From Fig. 12, we can see that the Fine AOD increased from 0.1 on 15 November to 0.5 on 18 November, and then decreased from 0.3 on 20 November to 0.1 on 22 November. Figures 11 and 12 show the development of a polluted aerosol event during the 15-22 November 2010.

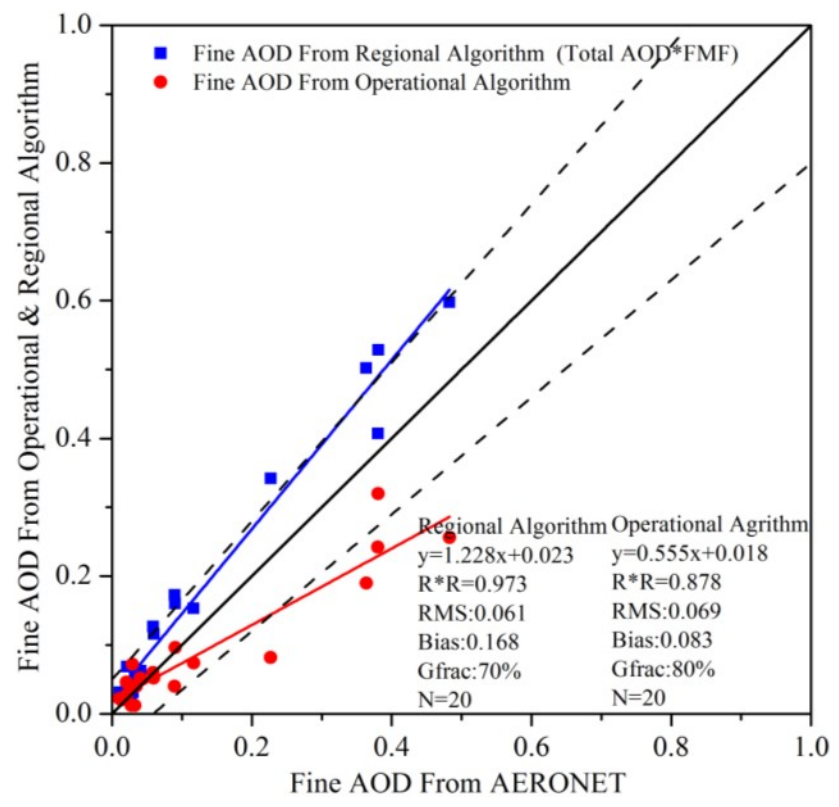

Fig. 9. Comparison of fine AOD retrieved present algorithm with those of operational algorithm at Xianghe from September to December in 2010.

\section{Conclusions}

The regional climate change of East Asia is affected by aerosols not only due to their large amount but also due to their different optical properties, from fine mode to coarse mode, causing different impacts. To obtain the regional climate effect of aerosol over East Asia, a measure of the anthropogenic aerosol optical properties are needed.

The main scientific objective of this paper aims to prospect the possibility of simultaneously retrieving the aerosol optical depth and fine-mode fraction (FMF) using polarized remote sensing, and to characterize the optical and physical properties of tropospheric aerosols and their temporal and spatial distributions over East Asia in order to study the anthropogenic aerosol optical properties over East Asia.

The algorithm of Dubovik et al. (2011) allows the retrieval of both the optical properties of aerosol and underlying surface over land, which can provide more detailed information about aerosol properties, including the particle size distribution, complex refractive index, and parameters characterizing aerosol particle shape and vertical distribution. But the algorithm of Dubovik is based on the optimized inversion, which requires applying complex multi-variable inversion algorithms. Such methods are time-consuming and challenging for implementation.

The sensitivity study show that the polarized reflectance of $670 \mathrm{~nm}$ and $865 \mathrm{~nm}$ has notably higher sensitivity to the details of aerosol optical depth and fine mode fraction, which means that the look-up table algorithm works efficiently for these two channels because they are sensitive to the 

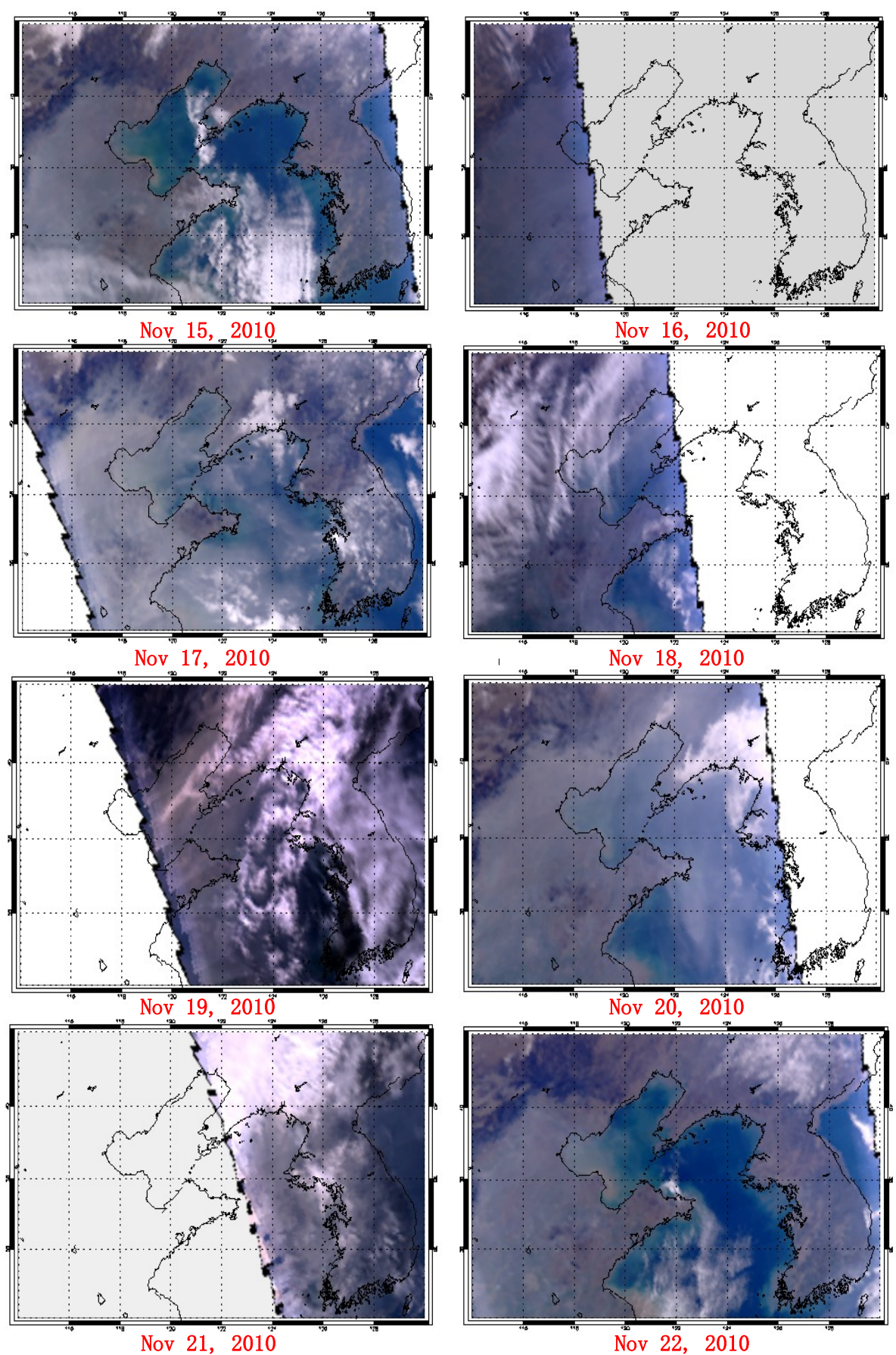

Fig. 10. RGB images $(0.44,0.565,0.675 \mu \mathrm{m})$ over East Asia captured by POLDER during 15-22 December 2010.

scattering of both fine and coarse mode aerosols. In order to study the optical and physical properties of tropospheric aerosols and their temporal and spatial distributions over the East Asia, a new aerosol retrieval algorithm using multi-angular total and polarized measurements based on the look-up tables of simulated satellite signals pre-computed for some limited selected scenarios of aerosols and underlying surface combinations is presented. The algorithm retrieves aerosol optical depth (AOD), fine-mode fraction (FMF) for studying the impact of aerosol on climate change.

To reduce the ambiguity in retrieval algorithm, the key characteristics of aerosol model over East Asia are constrained using the cluster analysis technique based on the AERONET sun-photometer observation over East Asia. The 

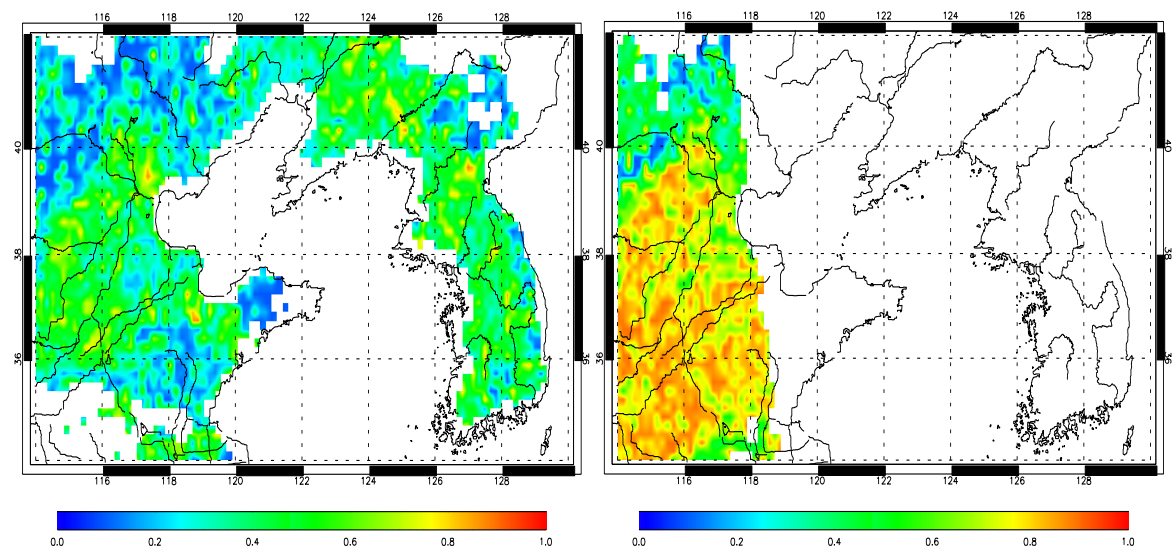

Nov 15, 2010

Nov 16, 2010
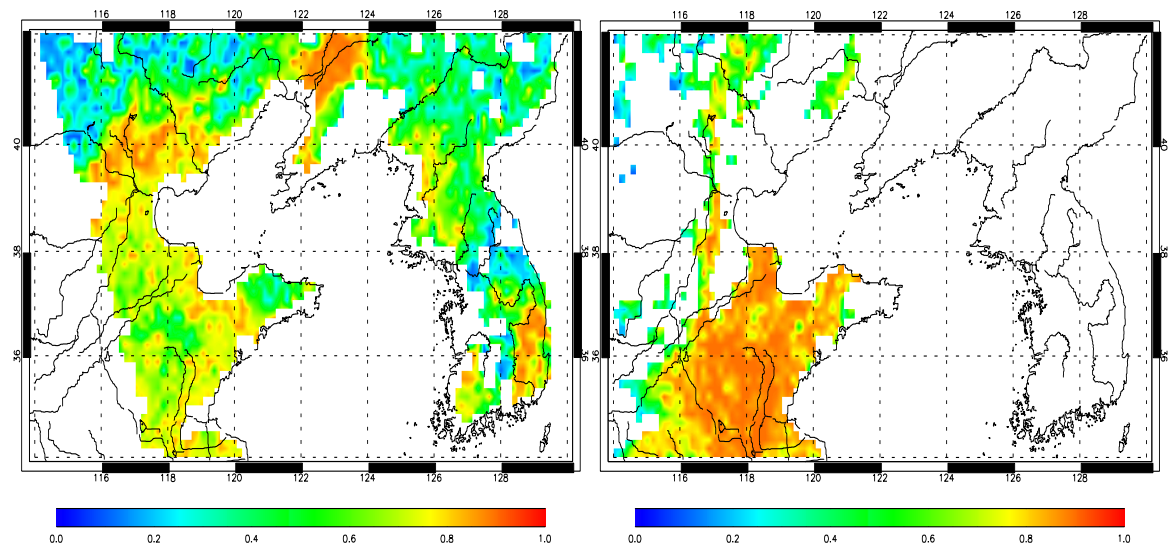

Nov 17, 2010

Nov 18, 2010

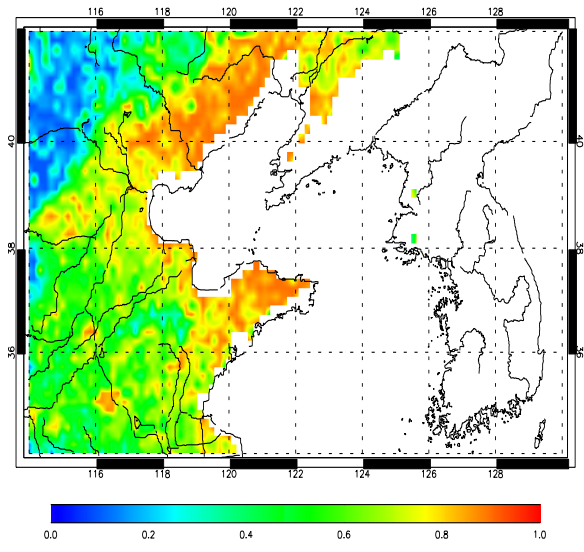

Nov 20, 2010

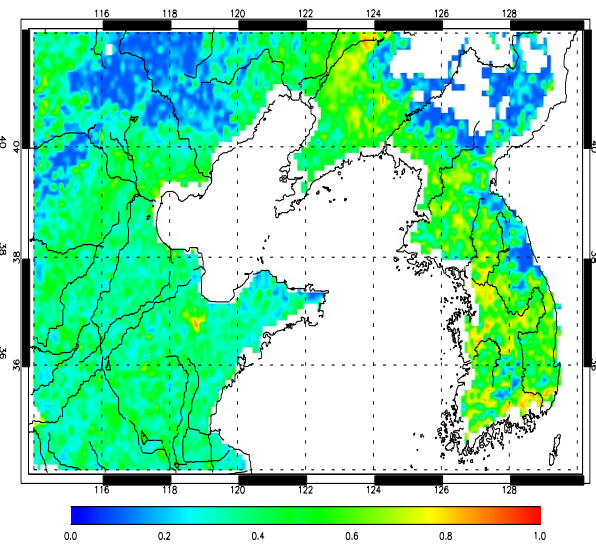

Nov 22, 2010

Fig. 11. Aerosol fine-mode (FMF) over the East Asia during 15-22 December 2010, except for 19 and 21 November due to cloud contaminated.

fine aerosol models are assumed to be spherical particles which can use the Mie model to calculate the scattering properties, while the coarse aerosol models are assumed to be spheroids particles which can use the T-matrix code to calculate the scattering properties. A mixing model of bare soil and green vegetation spectra and the Nadal and Breon model for the bidirectional polarized reflectance factor (BPDF) were used to simulate total and polarized surface reflectance of East Asia. In order to improve the accuracy of the BRDF and BPDF method, the NDVI were derived 

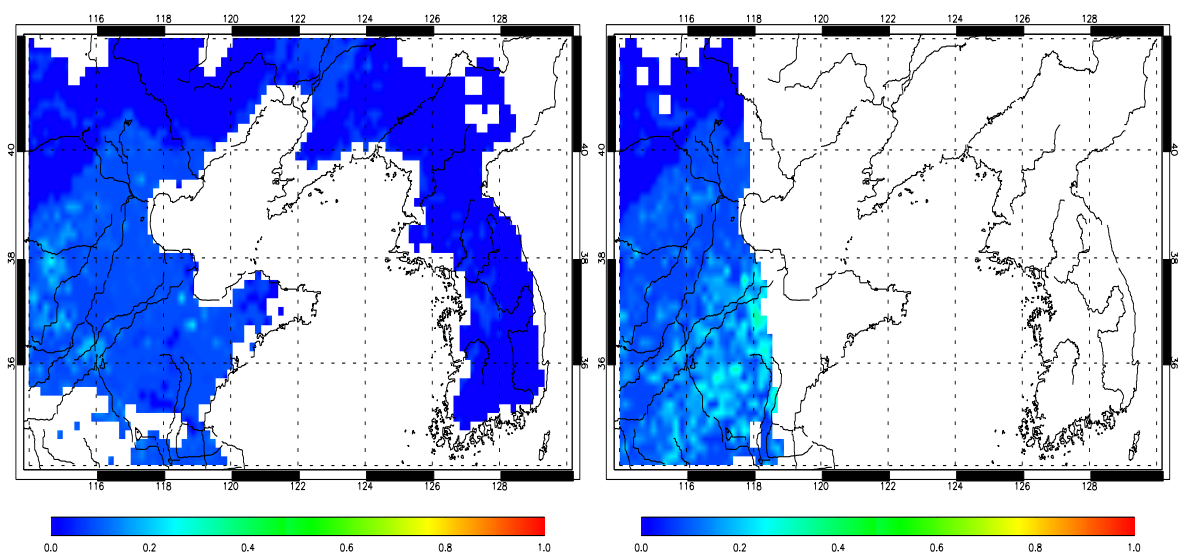

Nov 15, 2010

Nov 16, 2010

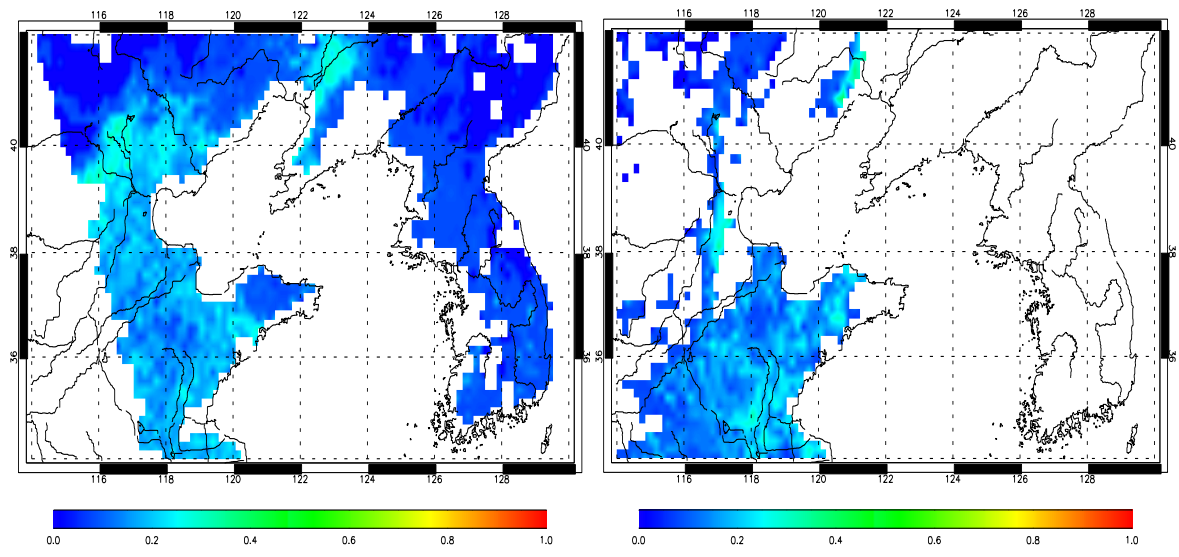

Nov 17, 2010

Nov 18, 2010

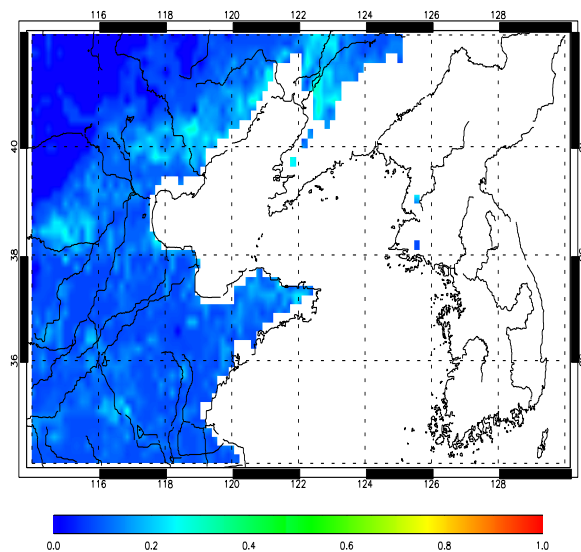

Nov 20, 2010

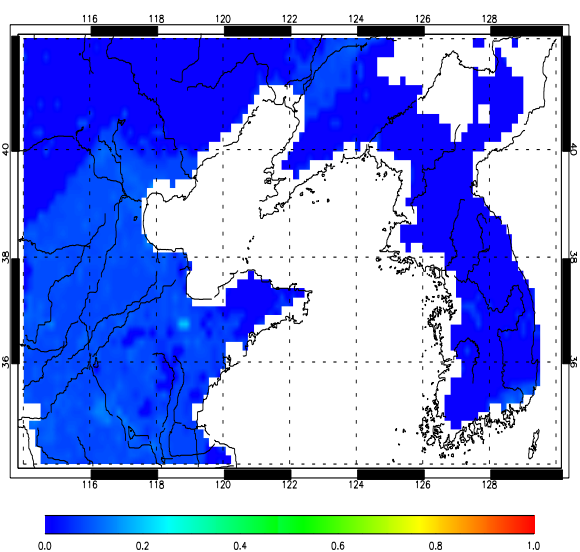

Nov 22, 2010

Fig. 12. Aerosol optical depth contributed by fine mode (Fine AOD) over East Asia during 15-22 December 2010, except for 19 and 21 November, due to cloud contaminated.

from the PARASOL measurements on the clear-sky conditions over a 30 day period.

By applying the present algorithm to POLDER measurements, three different aerosol cases of clear, polluted and dust are analyzed to test the algorithm. The comparison of retrieved aerosol optical depth (AOD) and fine-mode fraction (FMF) with those of AERONET sun-photometer observations show reliable results. Preliminary validation is encouraging. Using the new aerosol retrieval algorithm for multiangular total and polarized measurements, the spatial and 
temporal variability of anthropogenic aerosol optical properties over East Asia, which were observed during a heavy polluted event, were analyzed.

The proposed algorithm for retrieving the anthropogenic aerosols optical properties using multi-angular total and polarized measurements has demonstrated its potential for studying the climate effect of aerosol. However, the limited cases examined so far make comparison difficult, and further validations are needed.

Acknowledgements. This research was supported by the National Basic Research Program of China (973 Program) (Grant No: 2010CB950800), the Funds of the Chinese Academy of Sciences for Key Topics in Innovation Engineering (Grant No: KZCX2EW-QN311), the "Strategic Priority Research Program" of the Chinese Academy of Sciences-Climate Change: Carbon Budget and Relevant Issues (Grant No: XDA05100203), and the National Natural Science Foundation of China (Grant No: 41001207). The authors thank the ICARE Data and Services Center for providing access to the PARASOL data and products and for general assistance. We thank the O. Dubovik for providing access to the non-spherical database and for general assistance. We also thank the AERONET PIs Hongbin Chen and Philippe Goloub for their effort in establishing and maintaining the Beijing and Xianghe sites. The authors are grateful to reviewers for important comments related to this paper.

Edited by: A. Kokhanovsky

\section{References}

Andreae, M. O., Jones, C. D., and Cox, P. M.: Strong present-day aerosol cooling implies a hot future, Nature, 435, 1187-1190, doi:10.1038/nature03671, 2005.

Anderson, T., Charlson, R., Schwartz, S., Knutti, R., Boucher, O., Rodhe, H. and Heintzenberg, J.: Climate forcing by aerosols - A hazy picture, Science, 300, 1103-1104, 2003.

Anderson, T., Charlson, R., Bellouin, N., Boucher, O., Chin, M., Christopher, S., Haywood, J., Kaufman, Y., Kinne, S., Ogren, J., Remer, L., Takemura, T., Tanré, D., Torres, O., Trepte, C., Wielicki, B., Winker, D., and Yu, H.: An "A-Train" strategy for quantifying direct aerosol forcing of climate, B. Am. Meteorol. Soc., 86, 1795-1809, 2005.

Anderson, T. L., Wu, Y., Chu, D. A., Schmid, B., Redemann, J., and Dubovik, O.: Testing the MODIS satellite retrieval of aerosol fine-mode fraction, J. Geophys. Res., 110, D18204, doi:10.1029/2005JD005978, 2006.

Bates, T. S., Quinn, P. K., Coffman, D. J., Johnson, J. E., Miller, T. L., Covert, D. S., Wiedensohler, A., Leinert, S., Nowak, A., and Neusüb, C.: Regional physical and chemical properties of the marine boundary layer aerosol across the Atlantic during Aerosols99: An overview, J. Geophys. Res., 106, 20767-20782, 2001.

Bellouin, N., Boucher, O., Haywood, J., and Reddy, M.: Global estimates of aerosol direct radiative forcing from satellite measurements, Nature, 438, 1138-1140, doi:10.1038/nature04348, 2005.
Bellouin, N., Jones, A., Haywood, J., and Christopher, S. A.: Updated estimate of aerosol direct radiative forcing from satellite observations and comparison against the Hadley Centre climate model, J. Geophys. Res., 113, D10205, doi:10.1029/2007JD009385, 2008.

Bréon, F.-M. and Colzy, S.: Cloud Detection from the Spaceborne POLDER Instrument and Validation against Surface Synoptic Observations, J. Atmos. Sci., 38, 777-785, 1999.

Charlson, R. J. and Pilat, M.: Climate: The influence of aerosols, J. Appl. Meteorol., 8, 1001-1002, 1969.

Charlson, R. J., Schwartz, S. E., Hales, J. M., Cess, R. D., Coakley, J. A., Hansen Jr., J. E., and Hoffman, D. J.: Climate forcing by anthropogenic aerosols, Science, 255, 423-430, 1992.

Cheng, T. H., Gu, X. F., Yu, T., and Tian, G. L.,: The reflection and polarization properties of non-spherical aerosol particles, J. Quant. Spectrosc. Ra., 111, 895-906, 2010.

Cheng, T., Gu, X., Xie, D., Li, Z., Yu, T., and Chen, X.: Simultaneous retrieval of aerosol optical properties over the Pearl River Delta, China using multi-angular, multi-spectral, and polarized measurements, Remote Sens. Environ., 115, 1643-1652, 2011.

Chin, M., Ginoux, P., Kinne, S., Holben, B. N., Duncan, B. N., Martin, R. V., Logan, J. A., Higurashi, A., and Nakajima, T.: Tropospheric aerosol optical thickness fromt he GOCART model and comparisons with satellite and sunphotometer measurements, J. Atmos. Sci., 59, 461-483, 2002.

Chowdhary, J., Cairns, B., Mishchenko, M. I., Hobbs, P. V., Cota, G. F., Redemann, J., Rutledge, K., Holben, B. N., and Russell, E.: Retrieval of aerosol scattering and absorption properties from photopolarimetric observations over the ocean during the CLAMS experiment, J. Atmos. Sci., 62, 1093-1117, 2005.

Costa, M., Silva, A., and Levizzani, V.: Aerosol characterization and direct radiative forcing assessment over the ocean. Part I: Methodology and sensitivity analysis, J. Appl. Meteorol., 43, 1799-1817, 2004.

Delene, D. and Ogren, J.: Variability of aerosol optical properties at four North American surface monitoring sites, J. Atmos. Sci., 59, 1135-1150, 2002.

Deschamps, P. Y., Bréon, F.-M., Leroy, M., Podaire, A., Bricaud, A., Buriez, J. C., and Seze, G.: The POLDER mission: Instrument characteristics and scientific objectives, IEEE T. Geosci. Remote, 32, 598-615, 1994.

Deuzé, J. L., Bréon, F. M., Devaux, C., Goloub, P., Herman, M., Lafrance, B., Maignan, F., Marchand, A., Nadal, F., Perry, G., and Tanre, D.: Remote sensing of aerosols over land surfaces from POLDER-ADEOS-1 polarized measurements, J. Geophys. Res., 106, 4913-4926, 2001.

Diner, D. J., Martonchik, J. V., Kahn, R. A., Pinty, B., Gobron, N., Nelson, D. L., and Holben, B. N.: Using angular and spectral shape similarity constraints to improve MISR aerosol and surface retrievals over land, Remote Sens. Environ., 94, 155-171, 2005.

Dubovik, O. and King, M. D.: A flexible inversion algorithm for retrieval of aerosol optical properties from Sun and sky radiance measurements, J. Geophys. Res., 105, 20673-20696, 2000.

Dubovik, O., Holben, B. N., Eck, T. F., Smirnov, A., Kaufman, Y. J., King, M. D., Tanré, D., and Slutsker, I.: Variability of absorption and optical properties of key aerosol types observed in worldwide locations, J. Atmos. Sci., 59, 590-608, 2002a. 
Dubovik, O., Holben, B. N., Lapyonok, T., Sinyuk, A., Mishchenko, M. I., Yang, P., and Slutsker, I.: Non-spherical aerosol retrieval method employing light scattering by spheroids, Geophys. Res. Lett., 29, 1415, doi:10.1029/2001GL014506, 2002b.

Dubovik, O., Lapyonok, T., Kaufman, Y. J., Chin, M., Ginoux, P., Kahn, R. A., and Sinyuk, A.: Retrieving global aerosol sources from satellites using inverse modeling, Atmos. Chem. Phys., 8, 209-250, doi:10.5194/acp-8-209-2008, 2008.

Dubovik, O., Herman, M., Holdak, A., Lapyonok, T., Tanré, D., Deuzé, J. L., Ducos, F., Sinyuk, A., and Lopatin, A.: Statistically optimized inversion algorithm for enhanced retrieval of aerosol properties from spectral multi-angle polarimetric satellite observations, Atmos. Meas. Tech., 4, 975-1018, doi:10.5194/amt-4975-2011, 2011.

Evans, K. F. and Stephens, G. L.: A New Polarized Atmospheric Radiative Transfer Model, J. Quant. Spectros. Ra., 46, 413-423, 1991.

Hansen, J. E. and Travis, L. D.: Light scattering in planetary atmospheres, Space Sci. Rev., 16, 527-610, 1974.

Hansen, J. E., Sato, M., and Ruedy, R.: Radiative forcing and climate response, J. Geophys. Res., 102, 6831-6864, 1997.

Hansen, J. E., Sato, M., Lacis, A., Ruedy, R., Tegen, I., and Matthews, E.: Perspective: Climage forcings in the industrial era, P. Natl. Acad. Sci., 95, 12753-12758, 1998.

Hansen, J., Sato, M., Kharecha, P., and von Schuckmann, K.: Earth's energy imbalance and implications, Atmos. Chem. Phys., 11, 13421-13449, doi:10.5194/acp-11-13421-2011, 2011.

Hasekamp, O. P. and Landgraf, J.: Retrieval of aerosol properties over the ocean from multi-spectral single-viewing-angle measurements of intensity and polarization: retrieval approach, information content, and sensitivity study, J. Geophys. Res., 110, D20207, doi:10.1029/2005JD006212, 2005.

Hasekamp, O. P. and Landgraf, J.: Retrieval of aerosol properties over land surfaces: capabilities of multiple-viewing-angle intensity and polarization measurements, Appl. Optics, 46, 33323344, 2007.

Hasekamp, O. P., Litvinov, P., and Butz, A.: Aerosol properties over the ocean from PARASOL multiangle photopolarimetric measurements, J. Geophys. Res., 116, D14204, doi:10.1029/2010JD015469, 2011.

Hauser, A., Oesch, D., Foppa, N., and Wunderle, S.: NOAA AVHRR derived aerosol optical depth over land, J. Geophys. Res.-Atmos., 110, D08204, doi:10.1029/2004JD005439, 2005.

Haywood, J. and Boucher, O.: Estimates of the direct and indirect radiative forcing due to troposphere aerosols: A review, Rev. Geophys., 38, 513-544, 2000.

Holben, N., Eck, T. F., Slutsker, I., Tanré, D., Buis, J. P., Setzer, A., Vermote, E., Reagan, J. A., Kaufman, Y. J., Nakajima, T., Lavenu, F., Jankowiak, I., and Smirnov, A.: AERONET - A Federated Instrument Network and Data Archive for Aerosol Characterization, Remote Sens. Environ., 66, 1-16, 1998.

IPCC - Intergovernmental Panel on Climate Change: Climate Change 2007: The Physical Science Basis, Cambridge University Press, 2007.

Kaufman, Y. J., Tanre, D., and Boucher, O.: A satellite view of aerosols in the climate system, Nature, 419, 215-222, 2002.
Kaufman, Y. J., Boucher, O., Tanré, D., Chin, M., Remer, L. A., and Takemura, T.: Aerosol anthropogenic component estimated from satellite data, Geophys. Res. Lett., 32, L17804, doi:10.1029/2005GL023125, 2005.

Kleidman, R. G., O’Neill, N. T., Remer, L. A., Kaufman, Y. J., Eck, T. F., Tanre, D., Dubovik, O., and Holben, B. N.: Comparison of Moderate Resolution Imaging Spectroradiometer (MODIS) and Aerosol Robotic Network (AERONET) remote-sensing retrievals of aerosol fine mode fraction over ocean, J. Geophy. Res.Atmos., 110, D22205, doi:10.1029/2005JD005760, 2005.

Kokhanovsky, A. A., Breon, F.-M., Cacciari, A., Carboni, E., Diner, D., Di Nicolantonio, W., Grainger, R. G., Grey, W. M. F., Holler, R., Lee, K.-H.,, Li, Z., North, P. R. J., Sayer, A. M., Thomas, G. E., and von Hoyningen-Huene, W.: Aerosol remote sensing over land: A comparison of satellite retrievals using different algorithms and instruments, Atmos. Res., 85, 372-394, 2007.

Kokhanovsky, A. A., Deuzé, J. L., Diner, D. J., Dubovik, O., Ducos, F., Emde, C., Garay, M. J., Grainger, R. G., Heckel, A., Herman, M., Katsev, I. L., Keller, J., Levy, R., North, P. R. J., Prikhach, A. S., Rozanov, V. V., Sayer, A. M., Ota, Y., Tanré, D., Thomas, G. E., and Zege, E. P.: The inter-comparison of major satellite aerosol retrieval algorithms using simulated intensity and polarization characteristics of reflected light, Atmos. Meas. Tech., 3, 909-932, doi:10.5194/amt-3-909-2010, 2010.

Lee, K. H. and Kim, Y. J.: Satellite remote sensing of Asian aerosols: a case study of clean, polluted, and Asian dust storm days, Atmos. Meas. Tech., 3, 1771-1784, doi:10.5194/amt-31771-2010, 2010.

Litvinov, P., Hasekamp, O., Cairns, B., and Mishchenko, M.: Reflection models for soil and vegetation surfaces from multiple viewing angle photopolarimetric measurements, J. Quant. Spectrosc. Ra., 111, 529-539, 2010.

Litvinov, P., Hasekamp, O., and Cairns, B.: Models for surface reflection of radiance and polarized radiance: comparison with airborne multi-angle photopolarimetric meas-urements and implications for modeling top-of-atmosphere measurements, Remote Sens. Environ. 115, 781-792, 2011.

Mishchenko, M. I. and Travis, L. D.: Satellite retrieval of aerosol properties over the ocean using polarization as well as intensity of reflected sunlight, J. Geophys. Res., 102, 16989-17013, 1997.

Mishchenko, M. and Geogdzhayev, I. V.: Satellite remote sensing reveals regional tropospheric aerosol trends, Opt. Exp., 15, 7423-7438, 2007.

Nadal, F. and Bréon, F. M.: Parameterization of surface polarized reflectance derived from POLDER spaceborne measurements, IEEE T. Geosci. Remote, 37, 1709-1718, 1999.

Omar, A. H., Won, J. G., Winker, D. M., Yoon, S. C, Dubovik, O., and Mccormick, M. P.: Development of Global Aerosol Models using Cluster Analysis of AERONET Measurements, J. Geophys. Res.-Atmos, 110, D10S14, doi:10.1029/2004JD004874, 2005.

Remer, L., Kaufman, Y. J., Tanre, D., Mattoo, S., Chu, D. A., Martins, J. V., Li, R.-R., Ichoku, C., Levy, R. C., Kleidman, R. G., Eck, T. F., Vermote, E., and Holben, B. N.: The modis aerosol algorithm, products, and validation, J. Atmos. Sci., 62, 947-973, 2005. 
Von Hoyningen-Huene, W., Freitag, M., and Burrows, J. B.: Retrieval of aerosol optical thickness over land surfaces from top-of-atmosphere radiance, J. Geophys. Res., 108, 4260, doi:10.1029/2001JD002018, 2003.

Wang, M. and Gordon, H. R.: Radiance reflected from the oceanatmosphere system: Synthesis from individual components of the aerosols size distribution, Appl. Optics, 33, 7088-7095, 1994.

Waquet, F., Goloub, P., Deuzé, J.-L., Léon, J.-F., Auriol, F., and Verwaerde, C.: Aerosol retrieval over land using a multiband polarimeter and comparison with path radiance method, J. Geophys. Res., 112, D11214, doi:10.1029/2006JD008029, 2007.
Waquet, F., Cairns, B., Knobelspiesse, K., Chowdhary, J., Travis, L. D., Schmid, B., and Mishchenko, M. I.: Polarimetric remotesensing of aerosols over land, J. Geophys. Res., 114, D01206, doi:10.1029/2008JD010619, 2009a.

Waquet, F., Léon, J.-F., Cairns, B., Goloub, P., Deuzé, J.-L., and Auriol, F.: Analysis of the spectral and angular response of the vegetated surface polarization for the purpose of aerosol remote sensing over land. App. Optics, 48, 1228-1236, 2009 b.

Wiscombe, W. J.: Improved Mie scattering algorithms, Appl. Optics, 19, 1505-1509, 1981. 